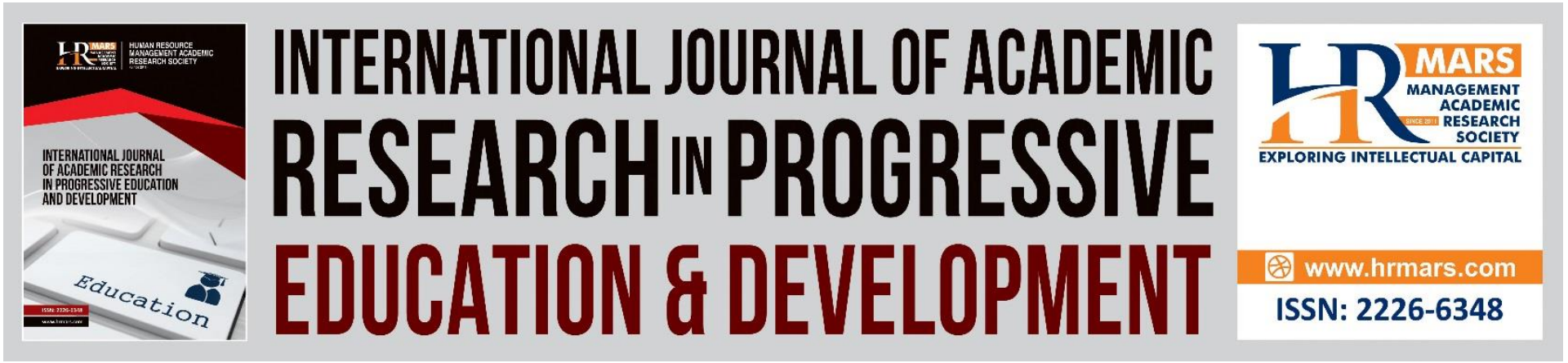

\title{
A Study on Doctor-Patient Relationship in Nangarhar: The Role of Trust
}

\section{Aimal Amiri, Imran Zafarzai}

To Link this Article: http://dx.doi.org/10.6007/IJARPED/v10-i3/10681

DOI:10.6007/IJARPED/v10-i3/10681

Received: 05 June 2021, Revised: 15 July 2021, Accepted: 29 July 2021

Published Online: 10 August 2021

In-Text Citation: (Amiri \& Zafarzai, 2021)

To Cite this Article: Amiri, A., \& Zafarzai, I. (2021). A Study on Doctor-Patient Relationship in Nangarhar: The Role of Trust. International Journal of Academic Research in Progressive Education and Development, 10(3), $1-10$.

Copyright: (C) 2021 The Author(s)

Published by Human Resource Management Academic Research Society (www.hrmars.com)

This article is published under the Creative Commons Attribution (CC BY 4.0) license. Anyone may reproduce, distribute, translate and create derivative works of this article (for both commercial and non-commercial purposes), subject to full attribution to the original publication and authors. The full terms of this license may be seen at: http://creativecommons.org/licences/by/4.0/legalcode

Vol. 10(3) 2021, Pg. 1 - 10

http://hrmars.com/index.php/pages/detail/IJARPED JOURNAL HOMEPAGE

Full Terms \& Conditions of access and use can be found at http://hrmars.com/index.php/pages/detail/publication-ethics 


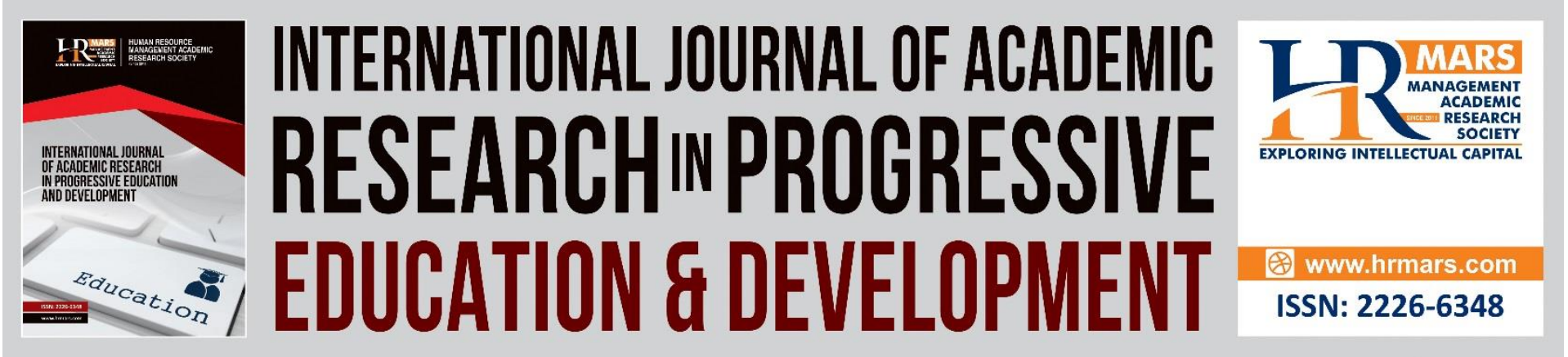

\title{
A Study on Doctor-Patient Relationship in Nangarhar: The Role of Trust
}

\author{
Aimal Amiri \\ Assistant Professor Forensic Medicine Department, Medical faculty, Nangarhar University, \\ Afghanistan \\ Email: aimalhospital1@gmail.com \\ Imran Zafarzai \\ Associate Professor Forensic Medicine Department, Medical faculty Nangarhar University, \\ Afghanistan \\ Email: imranzafarzai22@gmail.com
}

\begin{abstract}
Aside from the way that trust among specialists and patients is a wellspring of maintainable relations, influencing the conduct of the two players, it additionally has its remedial worth. In this study, a sociological perspective of trust have been investigated in Nangarhar Province. Doctors' way of understanding trust, nature of trust and complexity of trust was evaluated by direct response of patients. For accomplishment of research objective, data was collected from 200 individuals in Nangarhar Province, who recently availed health services for self or family. Content analysis is used for the research purpose. On the basis of collected responses in Nangarhar Province, it is clear that health care system number of significant changes occur in last 5 to 10 years. This paper means to develop a model of trust in the specialists' quiet relationship, dependent on subjective exploration; investigation of the substance of internet message sheets. The investigation uncovered that trust towards specialists is an aftereffect of covering and interpenetration of two degrees of trust: macro-scale and meso-scale. Macroscale trust can be viewed as a setting in which all the components of institutional trust are inserted. Though meso-trust (institutional) is portrayed as far as three measurements: altruism, fitness and respectability. Results also indicated that trust in a doctor-patient relationship is a social, complex and multi-dimensional phenomenon. Actions taken within just one of the dimensions will not yield expected outcome. On the other hand, however, any attempts at improving the situation will trigger a synergy effect to infuse the relation between doctor and patient with multitier trust, thus making it more effective, and in the long term, more efficient.
\end{abstract}

Keywords: Doctor, Patient, Trust, Nangarhar 


\section{Introduction}

Trust in relation; economic \& social, is highly significant and has become one of the hot topic of discussion for everyone. Trust between the relationship of patient and doctor is not only important but also has therapeutic value (Gilson, 2003). Presence or lack of trust is basically the outcome of actual experience, which in turn is a result of social context and based on the background of institution (Strategia Rozwoju Kapitalu Spolecznego, 2011-2020). Based on surveys in Afghanistan and in particular to Nangarhar province, level of trust between doctor and patient is much lower as compared to other Asian countries and other develop nations. Hence, research is needed to understand the complex and multifaceted relationship of doctor and patient.

Trust is basically an important component of a happy and satisfying relationship (Morgan, Hunt, 1994). It is also described as phenomena which lower the complexity of social relations (Skytt, Winther, 2011). Trust can be characterized as the conviction that one's partner will act in the combine interest and that neither one of the parties will actually endeavor to hurt their accomplice by exploiting their shortcomings (Gilson, 2003). It likewise implies the ability to put one's assets in an association with another gathering. Trust basically originates from a specific positive image based on previous shared relations just as from the apparent level of reliability of the accomplices. In addition, trust also act as an instrument which lessons the opportunist conduct (Skytt \& Winther, 2011).

Trust of a patient in doctor is very multidimensional behavior and can be defined in various ways in different disciplines. According to Thom at al (2002), trust is basically an allowance of faith based expectations or desires that a doctor will act with a particular goal in mind or in some specific way. According to Pearson and Raeke (2017), trust is an emotional trademark, where patients have a consoling sensation of confidence and reliance in a doctor's intention (Montague, 2010).

Patients trust in doctor is very important at every stage of treatment. It not only helps in building relation but also effects treatment outcomes in a positive manner (Hillen et al., 2011). Calnan (2016) documents that if a patient and doctor relationship is built on trust it will enhance the chances of improvement from the treatment because patient satisfaction plays a key role in in such relations (Calnan \& Rowe, 2006).

Studies suggest that in a patient and doctor relationship, timeframe should be reserved to make it workable for some level of trust to arise, in this manner patient can get complete benefit from the recommendation of doctor and can also make changes in their way of living, if suggested (Peilot et al., 2014).

Trust can be explored on various levels, some of them might be overlapping and others are not. As indicated by Sztompka (2015), there are slowly extending circles of trust which range from most substantial relation to the abstract behaviors towards social establishments and structures.

Trust on a specific specialist will ultimately reach out to encompass the facility where this specific physician works and when coming to the long term results it may start to apply to the social function of the physician and the whole medical care framework. This phenomena can also occur in reverse manner means trust of the organization can also influence the individuals to consult that specific doctor.

Confidence building in between two individuals is known as micro-scale (Interpersonal) trust. As in the process of trust building both parties ready to hand over their intellectual and physical asserts to the other party along with potential risks, vulnerability, misfortune and 
advantages involved in trust building process. In the specific scenario of micro trust, the roles can't be shifted to each other which mean that trust is allocated to one specific person from another (Skytt \& Winther, 2011).

Meso-scale (institutional) trust implies to the rules, norms and culture irrelevant to any kind of personification. It is also known as institutional trust which means that this trust is associated with the outcome of specific encounters and relations' of institutional nominees (Schee et al., 2007; Klipp, 2002).

Whenever, we are ready to rely on other person features like fitness, trustworthiness and altruism, we are actually building trust on it. Fitness is defined as the competence of the person on his words while trustworthiness is related to protect the customer's interest and at last altruism is defined as firmly stand with once own standards (Colquitt et al., 2007). In a relationship, trust from person can be juvenile in nature which means person can trust and distrust the same person in different perspectives. Same as the case with patient and doctor (Welch, 2006).

Macro-scale trust relates with public institutions or systems. It is basically a mutual relation between the system and the person. This trust is the common perception of any institute which was built by the nominees of institute or by the general public opinion. When a system or institution is not in compliance with its standards, then it is actually breaking the trust of the individuals who put faith in it (Abelsona et al., 2009).

Aforementioned suggests different types of trust are very closely related to each other. As in a macro-trust, meso-scale and micro-scale trust at respective level are examine. Micro-scale trust build up the meso and macro-scale trust as in a hospital patient and doctor trust comprises the hospital image which is a shape of meso-scale trust (Skytt \& Winther, 2011).

Trust is not only the subjective process but also the objective in parallel. When one has strong gut to develop new relationships and possibilities or even ready to new options, he is expressing strong trust building characteristics. In the parallel, the distress behavior or uncertainty can be more crucial to save the existing implanted trust (Grudzewski et al., 2009). Keeping in view the existing situation, this study examine the relationship between Patient and doctor base on trust in Nangarhar Province, Afghanistan.

\section{Health Care in Nangarhar}

Afghanistan is a developing country, which is recuperating from many years of conflicts and war. At the period, when interim government was established in 2002, Afghanistan had a crushed health framework; a very low degree of access to wellbeing centers and health services. Rate of mortality infants, children and maternal were highest in Afghanistan and specifically in Nangarhar as compare to other countries.

To accomplish fast extension of the geographic extent of fundamental wellbeing administrations in the remaking time frame, the public authority of Afghanistan characterized a function for the Service of Public Health based to a great extent on the stewardship work and contracted nearby and worldwide nongovernmental associations to convey a fundamental bundle of wellbeing administrations in many zones of the nation, with the public authority going about as immediate supplier of administrations in certain territories. The geographic extent of wellbeing administrations expanded quickly beginning in 2003, with contracted offices ready to build up administration conveyance frameworks inside a generally short time period. By the mid of 2004, managerial and monetary courses of action to convey 
the essential bundle were stretched out to locale in which $77 \%$ of inhabitants from Afghanistan dwell (Prestiz zawodów CBOS, 2013).

In the last 15 years, health care system in Nangarhar Province has gone through various significant changes. During the Taliban period, the health care system was utilized in a tyrant way to maintain the authority of the state. Patients were only considered as the severe beneficiary of the health care system. Subsequently a firm approach of doctor dominated relationship prevailed in the health care system. Doctors were seen as the heroes and idealized as the expert persons in their social and private life. These days, the Afghan constitution characterize that the health care service should administer the wellbeing of given local community. However, the main step taken by the Afghan government is to ensure that there should be availability of doctor, hospital or NGO for every citizen. Even every citizen have the right to access the doctor. As a result the patient and doctor relationship, which was diminished due to war circumstances in known in recovery phase. According to WHO (2018) report the stature of the doctor is on the rise as the social and economic reforms are on the way.

\section{Objective}

The key objective of present study is;

- To identify the role of trust in patient-doctor relationship in Nangarhar Province, Afghanistan.

\section{Methodolgy}

Many authors belief that there is no inclusive scale that measures trust between patient and doctor so, it is very hard to quantify. Hence, many researchers try to create and evaluate their own scales of trust therefor, this versatility results in more hard to comprehend the idea of trust. The investigation done for this article are aimed to provide the comprehension of trust between patient and doctor, which is the essence of trust in health care system. The parallel purpose of this article is to locate the type of trust between patient and the doctor by explaining the different variables which ensures the categorization of trust. This article also assists in the creation of applied model of trust in doctor patient relationship.

\section{Sample}

This study has deployed 200 samples of individuals from Nangarhar Province, who recently availed health services for self or family. Data was gathered in year 2020. Average age of the participants was 37 while the actual age bracket ranged from 22 to 53.

\section{Instrument Used for Research}

Primary instrument used for the purpose of data collection and use semi structured interview. Questionnaire for the interview was prepared by using different guidelines (Ullah,2020). Different necessary domains of interpersonal relationships were covered in the guidelines.

\section{Procedure}

Data was collected by visiting hospitals in Nangarhar Province and obtained the data from recently recovered and other patients who are not in very serious condition. The current research has deployed the given below two steps; 
DEVELOPMENT

Vol. 10, No. 3, 2021, E-ISSN: 2226-6348 @ 2021 HRMARS

\section{$1^{\text {st }}$ Step: Formation of interview guideline}

Firstly, various previous literatures were revised and then different subject matter experts (doctors, NGO's and burn center heads) were contacted so that to obtain a clear picture of the actual condition. Interview guidelines were designed after getting enough information from both sources. Guidelines were developed in such a way that made it convenient to acquire enough explanation of interpersonal relations and best ways to cope with the situation.

\section{$2^{\text {nd }}$ Step: Collection of data}

Second and final step was the collection of primary data from the respondents. For collection of data, firstly permission of the patient was taken and then data was collected in rapport building and actual interview.

\section{Analysis}

With the preset objective of the study, researchers planned to quantitative study in the form of an analysis of data collected through questionnaire in which the problem of patient trust in doctor was discussed. In this article researcher used the content analysis; a research method used in related studies. This procedure is useful for the systematic depiction of material of collected data (Ullah, Afghan, Afridi, 2019).

\section{Results}

\section{Macro Scale Trust}

Organizational trust in doctor-patient relationship is created and kept up in the setting of genuine and symbolic proceedings. Institutional trust involve systemic and macro structure incidents that ensures organization and running of healthcare system along with the compliance with institutional foundations. Perception of the above mention incidents put forward the idea, third party for the financing of health services and managing the benefits given to the population.

In optimistic way trust is deciphered as the fondness to have confidence in third parties ambitions and activities. Especially in circumstances that represents the risk of opportunistic behavior. Meanwhile, the study avoid from the close terms with the other party, it will be the form of restlessness on a macro scale this can be described in variety of methods. One of them is projection impact which means that identification proof of the individual of a given mechanism i.e. healthcare system with the mechanism itself. The qualities and properties of the system are naturally credit to all of its individual components.

The present study depicted that in Nangarhar, it is generally assumed that the doctors are system and system is long way from perfection. In Nangarhar, the sole representative of healthcare system encountered with the patients is the doctor. Thus, many people didn't get the entire idea of Afghan healthcare system.

It tends to be finalized on the basis of above evidence that doctor-patient relationship is interdicted in the social, structural and firmly implanted in the healthcare system. Health care system gives various standards of institutional guidelines and agreements which decides the affinities of macro trust. The arrangement of elements can be either perceived Barely (the rule of chess) or extensively (as a system of establishments and authoritative structures or even political bodies). 
In a doctor patient relationship the macro trust is additionally associated with once interpersonal demeanor for the environment and especially for the other people. Regardless of monitoring certain limitations i.e. data asymmetry and organizational relationship, patients can be happy to coordinate or not ready to cooperate. In the words of one of the respondents "Doctors behaviors towards patient's, results from the way that various patients argue with doctors rather than coordinating with them. I guess doctors prefer patients who have understanding of what they need regardless of their solid opinions".

Simultaneously the clients understand that doctor behavior to patients are heterogeneous and reliant on human factor according to one of the respondents "Healthcare system manages clinics and doctors who approach patients with differences as they have egotistical mentalities and deal them like numbers not as humans. Once, when I was in hospital morning shift nurse was kind and generous while the evening shift nurse was rude and careless. Second nurse wouldn't be a better caregiver regardless of what cash material or systems are provided".

Hence it is proved that the standard of health services and the trust between doctor and patient are only based on individual attitudes and organizational standards.

\section{Meso-Scale trust}

Trust is very crucial component of doctor and patient relationship even for a doctor appointment the predefined level of trust is required and this trust leads to the success of appointment of quality of communication and coordination and compliance with doctor's prescription. According to one of the respondents "it's understood that you can't visit a dentist unless you trust him just like if you wouldn't travel with a driver whom you don't trust because to reach safely at your required destination you should have trust in driver".

Research performed for this article proposed that experiences have prevented the residents of Nangarhar Province to fully trust the local doctors. The patients have low trust in the locally trained doctors. Hence, it is proved that the behavioral approach towards the doctor is more of the institutional type of trust. In the wording of a respondent "eight years ago, I suffered from a reproductive disorder for which I visited a number of doctors and specialists in all major healthcare facilities of Afghanistan. You will enjoy better health if you didn't trust any doctor. Otherwise trust on doctor is credulous."

Distrust may include wariness while mistrust involves more undesirable negativity. Mistrust, in this way, turns into a hazardous process, which tends towards social atomism. Some respondents also defend doctors as they said "I regained my life just because of doctors and during the journey, I met wonderful doctors who are really passionate and dedicated to their work. Also my family doctor is a nice human being who is good at his job." "I really trust on my children doctor. He is passionate, responsible and friendly and always tell us about the importance of healthy balance lifestyle'.

Form the above responses it is clear that if a doctor wants that their patients should have trust in him, he should be dedicated person, loyal with his job and passionate about his work.

\section{Conclusion}

In this study a sociological perspective of trust have been discussed. Doctors' way of understanding trust, nature of trust and complexity of trust was evaluated by direct response of patients. Content analysis is used for the research purpose. On the basis of collected responses, it is apparent that in health care system of Nangarhar Province, a number of 
significant changes have been occurred during last decade; from year 2010 to 2020. But still many people don't have direct access to the system. Doctor is the only representative of the system to whom people can directly meet and clarify their queries/problems. Trust plays a significant role in patient-doctor relationship. Success of a doctor and cure of patient both are linked with the trust between their relationships. Trust can help both doctor and patient to achieve their target. In Nangarhar province, still many improvements are needed because the level of trust between patient and doctor is not really established as in developed countries. Results also indicated that trust in a doctor-patient relationship is a social, complex and multidimensional phenomenon. Actions taken within just one of the dimensions will not yield expected outcome. On the other hand, however, any attempts at improving the situation will trigger a synergy effect to infuse the relation between a doctor and a patient with multitier trust, thus making it more effective, and - in the long term - more efficient. This is because a relationship based on trust will help avoid duplication of medical testing, noncompliance with medication regimens, unnecessary multiple appointments, and disregard for doctor's recommendations. Trust, as a symbolic component of a relationship, therefore, considered as an indispensable requisite for improving the effectiveness and efficiency of a health care system, because it permeates all the levels of a doctor-patient relationship. It eludes simple analysis of health economics, being rather part of multi-dimensional studies into the nature of relationship between service providers and service recipients, where involvement, reputation and communication are key words.

\section{References}

Abelsona, J., Millerb, F. A., Giacominia, M. (2009), What does it mean to trust a health system? A qualitative study of Canadian health care values, Health Policy, 91, pp. 63-70. Babbie, E. (2005), Badania spoáeczne w praktyce, PWN Warszawa, p. 342.

Brockner, J., Siegel, P. A., Daly, J. P., Tyler, T., Martin, Ch. (1997), When trust matters: The moderating effect of outcome favorability, Administrative Science Quarterly, Vol. 42, pp. 558-583.

Calnan, M., Montaner, D., Horner, R. (2005), How acceptable are innovative health-care technologies? A survey of public beliefs and attitudes in England and Wales, Social Science \& Medicine, 60(9), pp. 1937-1948.

Calnan, M., Rowe R. (2006), Researching trust relations in health care: Conceptual and methodological challenges - an introduction, Journal of Health Organization and Management, Vol. 20, No. 5, pp. 349-358.

Colquitt, J. A., Lepine, J. A., Zapata, C. P., Wild, R. E. (2011), Trust in typical and highreliability contexts: building and reacting to trust among firefighters, Academy of Management Journal, Vol. 54, No. 5, pp. 999-1015.

Colquitt, J. A., Scott, B. A., LePine, J. A. (2007), Trust, Trustworthiness, and Trust Propensity: A Meta-Analytic Test of Their Unique Relationships With Risk Taking and Job Performance, Journal of Applied Psychology, Vol. 92, No. 4, pp. 909-92.

Dietz, G., \& Hartog, D. N. (2006), Measuring trust inside organizations, Personnel Review, Vol. 35(5), pp. 557-588.

Franks, P., Fiscella, K., Shields, C. G., Meldrum, S. C., Duberstein, P., Jerant, A. F., Tancredi, D. J., Epstein, R. M. (2005), Are patients' ratings of their physicians related to health outcomes? Annals of Family Medicine, 3(3), pp. 229-234. 
DEVELOPMENT

Vol. 10, No. 3, 2021, E-ISSN: 2226-6348 @ 2021 HRMARS

Gilson, L. (2003), Trust and the development of health care as a social institution, Social Science \& Medicine, Vol. 56, pp. 1453-1568.

Goold, S. D., Klipp, G. (2002), Managed care members talk about trust, Social Science \& Medicine, Vol. 54, pp. 879-888.

Grudzewski, W. M., Hejduk, I. K., Sankowska, A., WaĔtuchowicz, M. (2009), Zarzqdzanie zaufaniem w przedsiĊbiorstwie, Wolters Kluwer Polska Sp. z o.o., Kraków.

Hillen, M. A., de Haes, H. C. J. M., Smets, E. M. A. (2011), Cancer patients' trust in their physician - a review, Psycho-Oncology, Vol. 20, pp. 227-241.

Lewis, J. D., Weigert, A. (1985), Trust as a Social Reality, Social Forces, Vol. 63, No. 4, pp. 967985.

Miles, M. B., Huberman, A. M. (2000), Analiza danych jakoĞciowych, Trans Humana, Biaáystok.

Meijboom, B., de Haan, J., Verheyen, P. (2004), Networks for integrated care provision: an economic approach based on opportunism and trust, Health Policy, Vol. 69, p. 36.

Montague, E. (2010), Validation of a trust in medical technology instrument, Applied Ergonomics, 41, pp. 812-821.

Montague, E. N. H., Kleiner, B. M., Winchester, W. W. (2009), Empirically understanding trust in medical technology, International Journal of Industrial Ergonomics, 39, pp. 628-634.

Morgan, R. M., Hunt, S. D. (1994), The commitment - trust theory of marketing, Journal of Marketing, Vol. 58, No. 3, pp. 20-38.

Ostrowska, A. (1981), Rola pacjenta i lekarza: zmiany w scenariuszu, Studia Socjologiczne, 3, p. 81.

Pearson, S. D, Raeke, L. H. (2000), Patients' trust in physicians: Many theories, few measure, and little data, Journal of General Internal Medicine, 15, pp. 509-513.

Peilot, B., Andrell, P., Samuelsson, A., Mannheimer, C., Frodi, A., Sundler, A. J. (2014), Time to gain trust and change-Experiences of attachment and mindfulness-based cognitive therapy among patients with chronic pain and psychiatric co-morbidity, International Journal of Qualitative Stud Health Well-being, Vol. 9, Article ID 24420.

Rudzewicz, A. (2009), Zaufanie - przegląd koncepcji, In: Kontrowersje wokóá marketingu w Polsce. NiepewnoĞü i zaufanie a zachowania nabywców (red.) L. Garbarski, J. Tkaczyk, Wydawnictwa Akademickie i Profesjonalne, Warszawa.

Skytt, Ch. B., Winther, L. (2011), Trust and local knowledge production: Interorganisational collaborations in the Sønderborg region, Denmark, Geografisk Tidsskrift-Danish Journal of Geography, 111(1), pp. 27-41.

Straten, G. F., Friele, R. D., Groenewegen, P. P. (2002), Public trust in Dutch health care, Social Science and Medicine, Vol. 55, No. 2, pp. 227-34.

Sztompka, P. (2007), Zaufanie. Fundament spoáeczeĔstwa, Wydawnictwo Znak, Kraków, p. 104.

Thom, D. H., Kravitz, R. L., Bell, R. A., Krupat, E, Azari, R. (2002), Patient trust in physician: Relationship to patient requests, Family Practice, 19(5), pp. 476-483.

Welch, M. (2006), Rethinking relationship. Management, Exploring the dimension of trust, Journal of Communication Management, Vol. 10, No. 2, pp. 138-155.

Wáodarczyk, W. C. (1998), Reforma opieki zdrowotnej w Polsce. Studium polityki zdrowotnej, Uniwersyteckie Wydawnictwo Medyczne „Vesalius”, Kraków, p. 95. 
Van der Schee, E., Braun, B., Calnan, M., Schnee, M., Groenewegen, P. P. (2007), Public trust in health care: A comparison of Germany, The Netherlands, and England and Wales, Health Policy, Vol. 81, pp. 56-67.

Van der Schee, E., Groenewegen, P. P., and Friele, R. D. (2006), Public trust in health care: a performance indicator? Journal of Health Organization and Management, Vol. 20, No. 5, pp. 468-476.

Timmons, S, Harrison-Paul, R, Crosbie, B. (2008), How do lay people come to trust the Automatic External Defibrillator? Health Risk \& Society, 10(3), pp. 207-220.

Ullah, M. (2020). Women Empowerment and Social Development in Afghanistan through Micro Finance. International Journal of Academic Research in Business and Social Sciences, 10(12), 377-389.

Zucker, L. G. (1986), Production of trust: institutional sources of economic structure, Research in Organizational Behaviour, Vol. 8, pp. 53-111. 